\title{
How anticipated regret influences the effect of economic animosity on consumers' reactions towards a foreign product
}

\author{
Authors: Dr Hina Khan, Dr. Ahmad Daryanto and Dr. Chihling Liu ${ }^{1}$ \\ Department of Marketing, Lancaster University Management School, Lancaster University \\ U.K.
}

\begin{abstract}
We use regret theory to explain the negative effect of economic animosity on consumers' reactions towards a foreign product (i.e., product judgment and reluctant to buy). We conduct our study in Taiwan by collecting data via an online survey. Our results show that consumers' economic animosity increases their anticipated regret towards purchasing a foreign product originating from a target market of animosity. Specifically, anticipated regret is found to mediate the link between economic animosity and foreign product judgment, which in turns affects consumers' reluctance to buy. Our study is the first to consider the role of anticipated regret in explaining the negative effect of economic animosity on consumers' reactions towards a foreign product. We also contribute to research by introducing two antecedents of economic animosity: perceived economic competition and consumer ethnocentrism.
\end{abstract}

Keywords: consumer behavior; emotion; economic animosity; anticipated regret; consumer ethnocentrism; structural equation modelling

\footnotetext{
${ }^{1}$ All authors contributed equally to this work.
} 


\section{Introduction}

Persistent feelings of economic threats from a neighboring country can result in economic animosity (De Nisco, Mainolfi, Marino, \& Napolitano, 2016; Nijssen \& Douglas, 2004). Despite extant research on general animosity, previous research has mainly focused on the war context and less on economic rivalry, which is currently omnipresent. In this research, we seek to investigate and elucidate the role of economic animosity and anticipated regret in the situation of economic rivalry. We chose Taiwan/South Korea as our research context because its economic rivalry has in recent years intensified. In 2013, for example, the Taiwanese Fair Trade Commission handed down a hefty fine against the South Korean company Samsung after it was found hiring students to write malicious online reviews about its Taiwanese rival HTC (Harris, 2013). Such rivalry episodes can lead to increased economic animosity among consumers, thus having a profound impact on consumer behavior (Nes, Yelkur, \& Silkoset, 2012). Our emerging findings also help inform the challenges international firms may face when entering or operating in a foreign market.

Economic animosity is one of the dimensions of the general animosity construct conceptualized by the well-known Animosity Model developed by Klein, Ettenson, and Morris (1998). They define general animosity as "the remnants of antipathy related to previous or ongoing military, political, or economic events" (Klein, Ettenson, \& Morris, 1998, p.90). According to the authors, animosity is a two-dimensional construct comprising both war and economic animosity. However, while the meaning of war animosity has been clearly established, the notion of economic animosity is not yet well explained or clearly defined in the literature. For instance, in Klein et al.'s (1998) theorizing, economic animosity is concerned with economic events, whereas others relate it to the presence of continuous economic threats from the target country of animosity (e.g., De Niscoet al., 2016). In this 
article, we define 'economic animosity' as a strong dislike or antipathy toward another country or marketplace as a consequence of the ongoing and/or temporary economic threats from that country or marketplace. Specifically, we introduce perceived economic competition (PEC) as a potential antecedent of economic animosity that captures consumers' perceived economic rivalry with the other country or marketplace.

We also consider consumer ethnocentrism (CET) as another antecedent of economic animosity. Klein et al. (1998) included CET in their original animosity model, but they did not model the direct link between CET and general animosity and vice versa, despite the fact that the authors reported a higher correlation between the two constructs in their data. Subsequent research has since tested this link but the results have been mixed, as we will go on to argue in the next section. Our study thus seeks to contribute to the CET-Animosity literature by examining the link between economic animosity and CET. Furthermore, as CET explains consumers' general tendency to refuse foreign products, animosity is often geared towards a specific country (Klein et al., 1998). Therefore, the inclusion of CET in our model would help explain consumers' evaluations of foreign products. In making this inclusion, we offer new insights into the effect of CET on animosity in general.

Earlier research has shown a negative impact of general animosity on consumers' foreign product purchase decisions (Klein et al., 1998). That is, when consumers experience animosity towards a certain country, they become reluctant to consume products from that country. However, this body of research claims that such animosity does not interfere with consumers' judgment about foreign product quality. In contrast to this claim, nonetheless, more recent studies on animosity have pointed to the negative effect of animosity on consumers' foreign product judgment. In other words, consumers who experience animosity towards a foreign country will be biased against products from that country (Russell \& 
Russell, 2010; Shoham, Davidow, Klein, \& Ruvio, 2006). They will assess the quality of products from the target country of animosity in a negative light. This finding points to the potential role of animosity in influencing consumers' foreign product judgment. Nonetheless, we still know little about the mechanism(s) through which animosity affects foreign product judgment. We suggest a possible, to date unexplored, explanation of how economic animosity may have an impact on product judgment. We consider an emotional response triggered by economic animosity. Drawing on the well-established regret theory, we propose that the negative effect of economic animosity on foreign product judgment can be potentially explained, at least in part, by consumers' anticipated regret with respect to future purchase decisions. Regret theory suggests that consumers anticipate regret before they make a purchase decision (e.g., 'how would I feel if I bought a foreign product from an economic rival?'). We argue that anticipated regret may be a mechanism that mediates the relationship between economic animosity and foreign product judgment, thus explaining how economic animosity undermines consumers' foreign product judgment (e.g., anticipated regret may occur as one anticipates the negative affective outcome of buying a product from an economic rival) (Schih \& Chau, 2011; Zeelenberg, 1999). We argue that anticipated regret may be a mechanism that mediates the relationship between economic animosity and foreign product judgment, thus explaining how economic animosity undermines consumers' foreign product judgment (e.g., anticipated regret may occur as one anticipates the negative affective outcome of buying a product from an economic rival).

Our contribution to the international marketing literature is twofold. First, we develop and test the economic animosity model that links economic animosity with anticipated regret to explain consumers' foreign product judgment. We use regret theory as a theoretical lens to 
explain the mechanism through which economic animosity affects consumers' foreign product judgment and their reluctance to buy foreign products. To the best of our knowledge, we are the first to introduce anticipated regret into the economic animosity model. Second, we are also the first to hypothesize and examine the role of perceived economic competition (PEC) and consumer ethnocentrism (CET) as antecedents in influencing economic animosity. These findings extend limited past research on the role of economic rivalry in economic animosity by showing the underlying antecedents that underpin consumers' economic animosity.

In the next sections, we detail our proposed conceptual framework, report the findings of our study and conclude by discussing the theoretical and managerial implications of these findings with suggestions for further research.

\section{Conceptual development}

\subsection{Anticipated regret and economic animosity}

Regret theory suggests that people anticipate regret when making decisions in order to avoid experiencing it. Regret refers to a negative emotion experienced by a person upon receiving negative decision outcomes or processes (Zeelenberg \& Pieters, 2007). When people experience regret they engage in counterfactual thinking of 'what could have been' (i.e., hypothetical scenarios about better possible alternatives).

Early research findings in psychology on regret revealed that people experience regret when the outcomes of their decisions do not meet their prior expectations (i.e., when the outcome of a decision is not as good as what could have been if a different decision had been made). Yet, such comparative evaluation of negative decision outcome is not the only source of regret. Connolly and Zeelenberg (2002) found that feelings of self-blame for having made a poor decision could also trigger regret. In other words, if people make a decision that 
cannot be justified in retrospect, they will experience self-blame and thus regret, even if the decision outcome is positive (Connolly and Zeelenberg, 2002). For instance, in our research context, we argue that if consumers inadvertently purchased a foreign product from a target country of animosity, even though the product may prove to be of good value, they would still experience regret because the purchase does not conform to the moral principle (e.g., ethnocentrism) upheld by their social network. When regret occurs, whether or not anticipated, consumers may engage in actions to undo their earlier purchase decisions (e.g., return the product purchased).

In addition to studies on experienced regret, prior research has documented that people anticipate regret prior to making a decision (Shih \& Schau, 2011, Zeelenberg, 1999). That is, when making decisions, people take into account their emotional reactions to possible outcomes by mentally stimulating different scenarios that 'could have been'. In the context of consumer decision-making, there are several possible scenarios in which people may anticipate regret (Janis \& Mann, 1977, Zeelenberg, 1999, Zeelenberg \& Pieters, 2007). Firstly, people anticipate regret about a purchase decision if they are aware that the product they prefer is not necessarily superior to another alternative. Therefore, in scenarios where choices can be made, people often spend more time in deciding which product to buy in order to avoid regret. Secondly, people anticipate regret if they can foresee that the negative consequences of a decision could materialize almost immediately after the decision is made. This is because consumers tend to put more value on decision outcomes that are more proximal rather than distant. Thirdly, according to Janis and Mann (1977), there is a social aspect of regret anticipation. People may also become more prone to anticipate regret to avoid bad outcomes when their significant others are involved in the decision-making. Finally, Zeelenberg (1999) found that people anticipate regret in scenarios where they expect 
to receive feedback upon making a decision. For example, if one has to decide which comparable high-tier journals to submit a manuscript to, one may anticipate regret before making the decision (i.e., which journals may be a poorer fit and thus increase chances of rejection). The anticipation of regret then helps the author to decide a suitable journal outlet for manuscript submission.

Taken together, we argue that animosity can have an impact on people's tendency to anticipate regret with respect to buying a foreign product from a target country of animosity. That is, animosity can elicit regret anticipation. For example, buying a product from a target country of animosity can be considered threatening to one's beliefs and moral principles. A person may thus foresee such threats and refrain from purchasing the product to avoid postdecisional regret (e.g., in this case regret occurs when one buys something that may challenge one's beliefs of animosity). This leads us to the following hypothesis:

Hypothesis 1. Economic animosity has a positive impact on anticipated regret.

\subsection{The Impact of anticipated regret on product judgment and reluctance to buy a foreign product}

We argue that anticipated regret, as a result of animosity, can impact people's evaluation of a foreign product. That is, to maintain negative attitude-behavior consistency, people may perceive the product to be of a lower quality (i.e., the spill-over effect of consumer animosity on foreign product judgment). Furthermore, such negative attitude-behavior maintenance can be seen as a self-control mechanism through anticipated regret (Inman, 2007). That is, anticipated regret functions as a prevention strategy that works to undermine consumers' perceived quality of foreign products. In so doing, consumers can prevent themselves from purchasing a product from a target country of animosity, resulting in the actual experience of 
regret. This logic can be applied when a consumer engages in a decision-making process to either buy a product that comes from a target country of animosity (say, product A) or a similar product that is not from a target country of animosity (say, product B). When the consumer considers buying product $\mathrm{A}$, s/he will be more likely to use animosity-triggered anticipated regret as the preventive strategy to combat his/her desire to purchase the product. This animosity-related anticipated regret strategy would not be present if the consumer is considering buying product B that does not originate from the target country of animosity. Thus, a consumer is more likely to anticipate regret if $\mathrm{s} / \mathrm{he}$ is considering purchasing a product from a target country of animosity than if s/he is buying a similar product not from a target country of animosity.

This leads us to the following hypotheses:

H2. Anticipated regret has a negative impact on foreign product judgment.

H3. Anticipated regret has a positive impact on reluctance to buy foreign products.

\subsection{Economic animosity, foreign product judgment and reluctance to buy foreign products}

In Klein et al.'s (1998) original animosity model, animosity can affect consumers' intention to buy a foreign product independent of product judgment. In other words, in this case animosity does not undermine perceptions of product quality. However, recent studies reveal that animosity can affect perceptions of product quality if the emotion of anger is perceived to be personal and culturally specific (Russell \& Russell, 2010; Shoham et al., 2006). Using cognitive dissonance theory (Festinger, 1962), Shoham et al. (2006) argue that the act of undermining perceived foreign product quality serves to reduce cognitive dissonance (e.g., to 
ensure consistent negative attitudes toward both the target country of animosity and its products).

Following this logic, we expect that economic animosity may impact product judgment in the present research context where cognitive dissonance occurs when Taiwanese consumers juggle between two conflicting beliefs they have towards South Korea: (1) a positive belief about their close cultural proximity (Jae-Woong, Samsup, \& Jaemin, 2014; Su, Huang, Brodowsky, \& Kim, 2011); and (2) a negative sentiment about their economic rivalry (Yu-An, Phau, \& Lin, 2010). An alternative explanation is the self-defense mechanism theory (Baumeister, Dale, \& Sommer, 1998). According to this theory, consumers may engage in self-deception to maintain their favorable beliefs if they experience an internal or external event that may violate and alter these beliefs (Baumeister et al., 1998). As such, we predict that consumers may engage in self-deception by lowering the perceived quality of a foreign product in order to maintain their anger towards the target country of economic animosity. This leads us to the following hypotheses:

H4. Economic animosity has a negative impact on foreign product judgment.

H5. Economic animosity has a positive impact on reluctance to buy foreign products.

Prior research has also pointed to a positive link between foreign product judgment and consumer willingness to buy foreign products (Funk, Arthurs, Treviño, \& Joireman, 2010). We therefore expect the following:

H6. Foreign product judgment has a negative impact on reluctance to buy foreign products.

\subsection{The mediation effect of anticipated regret}


This study also seeks to understand the mechanism through which economic animosity impacts foreign product judgment. As argued by several researchers, mediation analysis is needed to find out why an effect occurs (i.e., from economic animosity to product judgment) (Baron and Kenny, 1986; Zhao, Lynch and Chen, 2010; Pieters, 2017.

To the extent that consumers develop economic animosity, we argue that the feelings of anticipated regret are activated as a preventive strategy to avoid bad purchase outcomes. These feelings of anticipated regret may be consciously processed to motivate the consumer to contemplate more thoroughly before making a final decision (Janis and Mann, 1977). Indeed, according to Baumeister et al. (2011, p.5) “anticipated regret changes consumers' decision processes toward greater vigilance... and promotes risk avoidance". Anticipating how one's self might feel after a product purchase from a target country of animosity would thus lead to a reduction in one's purchase intention (i.e., avoiding making a regrettable decision). In these terms, feelings of anticipated regret would result in a negative impact on purchase intention.

As been explained above, economic animosity can activate anticipated regret, which might then lead the consumer to downgrade the perceived quality of a product from a target country of animosity. Hence, we use regret theory to develop hypotheses about the effect of economic animosity on anticipated regret and about the link between anticipated regret, product judgment, and reluctance to buy a foreign product. This leads us to the following hypotheses:

H6a. Anticipated regret mediates the effect of economic animosity on foreign product judgment. 
H6b. Anticipated regret mediates the effect of economic animosity on reluctance to buy a foreign product.

\subsection{Antecedents of economic animosity}

In this section, we propose two constructs that may serve as antecedents of economic animosity in our model: perceived economic competition (PEC) and consumer ethnocentrism (CET). Identifying the antecedents that impact economic animosity is important for advancing our understanding of the role of economic animosity in the context of economic rivalry between countries.

\subsection{Perceived economic competition (PEC) and its relationship with economic animosity}

We define PEC as an individual's perception of the degree of economic competition between the home market and a foreign market (i.e., Taiwan and South Korea in this case). It also reflects the extent to which a consumer's home market faces economic challenges posed by the foreign market. Adapting the conceptualization of the antecedents of animosity from Leong, Cote, Ang, Tan, Jung, Kau, and Pornpitakpan (2008), we argue the locus of attribution in the perception of economic rivalry could be a foreign market. The foreign country can be viewed as having control over the magnitude of the economic competition (e.g., the foreign country could relax its aggressive economic policy towards the home country). When the level of economic competition is perceived to be high, the rival country can be perceived as a threat because the competition may increase economic hardship in the home country (Yu-A et al., 2010). As a result, consumers' animosity towards countries of economic competition may be expected to develop over time. This leads us to the following hypothesis: 
H7. Perceived economic competition has a positive impact on economic animosity.

\subsection{Consumer ethnocentrism (CET) and its relationship with economic animosity}

CET has been defined as "the beliefs held by consumers about the appropriateness, indeed morality, of purchasing foreign made products" (Shimp \& Sharma, 1987, p.280). Although subsequent studies have examined the relationship between CET and consumer animosity, they have not modelled the nature of this relationship consistently (see Table 1). 
Table 1. Selected research examining the relationship between CET and consumer animosity

\begin{tabular}{|c|c|c|c|c|}
\hline Author, Year & Journal & Findings & Sample & Target Country \\
\hline De Nisco et al., (2016) & European Management Journal & $\mathrm{AN} \rightarrow \mathrm{CET}$ & Italian and Spanish & Germany \\
\hline Chan, Chan, and Leung (2010) & Journal of Global Marketing & $\mathrm{AN} \rightarrow \mathrm{CET}$ & $\begin{array}{l}\text { graduate students } \\
\text { HK students }\end{array}$ & Vietnam, India \\
\hline Jimenez and San MartÃn (2010) & International Business Review & $\mathrm{AN} \rightarrow \mathrm{CET}$ & Spanish car owners & South Korea \\
\hline Nijssen and Douglas, (2004) & $\begin{array}{l}\text { International Journal of Research in } \\
\text { Marketing }\end{array}$ & $\mathrm{AN} \rightarrow \mathrm{CET}$ & Dutch consumers & Germany \\
\hline Rose, Rose, and Shoham (2009) & Journal of Consumer Marketing & Correlational & $\begin{array}{l}\text { Arab Israelis } \\
\text { Consumers }\end{array}$ & $\begin{array}{l}\text { European } \\
\text { Countries }\end{array}$ \\
\hline Maher, Clark and Maher (2010) & Journal of Consumer Marketing & Correlational & US consumers & Japan \\
\hline Klein $(2002)$ & $\begin{array}{l}\text { Journal of International Business } \\
\text { Studies }\end{array}$ & Correlational & US consumers & Japan \\
\hline Klein et al., (1998) & Journal of Marketing & $\begin{array}{l}\text { Correlational } \\
\mathrm{r}(\text { war })=.47 ; \\
\mathrm{r}(\text { economic })=.2 \\
7 \\
\mathrm{r}(\text { animosity })=.4 \\
6\end{array}$ & Chinese consumers & Japan \\
\hline Funk et al., (2010) & $\begin{array}{l}\text { Journal of International Business } \\
\text { Studies }\end{array}$ & $\begin{array}{l}\text { Correlational; } \\
\mathrm{r}=0.25\end{array}$ & US consumers & Japan \\
\hline Hoffman, Mai, and Smirnova, (2011) & $\begin{array}{l}\text { Journal of Marketing Theory and } \\
\text { Practice }\end{array}$ & $\begin{array}{l}\text { Correlational; } \\
r=0.09 \\
\text { (German } \\
\text { consumers) and } \\
r=0.28 \\
\text { (Russian } \\
\text { consumers) }\end{array}$ & $\begin{array}{l}\text { German } \\
\text { consumers, Russian } \\
\text { consumers }\end{array}$ & $\begin{array}{l}\text { France, US, } \\
\text { Germany/Russia }\end{array}$ \\
\hline Wang, $\mathrm{He}$, and Li, (2012) & Asia Pacific Business Review & $\begin{array}{l}\text { Correlational; } \\
\mathrm{r}=0.23 \text { and } 025\end{array}$ & Chinese consumers & Japan \\
\hline
\end{tabular}


Parker, Hatyko, and Hermans (2011)

Harmeling Magnusson, and Singh,

(2015)
Journal of Global Marketing

Journal of International Business

Studies
Correlational

Correlational,

0.37 and 0.39
Chinese consumers

US consumers

Chinese consumers
US

Russia (for US

consumers)

Japan (for Chinese

consumers)

Note: $\mathrm{AN}=$ consumer animosity; $\mathrm{CET}=$ consumer ethnocentrism, $\mathrm{r}=$ correlation coefficient 
Some studies adopt Klein's theory (Klein et al., 1998), which posited no relationship between the two constructs (i.e. no direct direction was specified from animosity to CET or vice versa). However, while no relationship was posited, these studies have shown that CET and animosity were empirically correlated and reported the size and magnitude of the correlations (e.g., Funk,et al., 2010; Harmelinget al., 2015; Hoffmann et al., 2011; Maher et al., 2010; Parker et al., 2011; Rose et al., 2009; Wang et al., 2012). Many of these studies reported the correlation was significant with effect sizes ranging from moderate to large. That said, these studies failed to explain clearly the rationale of why there was no direct effect posited between CET and animosity. For instance, Klein contended that, "animosity is comprised of consumer feelings toward a specific country, whereas consumer ethnocentrism concerns attitudes toward buying goods from all foreign countries" (Kleine, 2002, p.348). However, she does not adequately explain why no direct effect was hypothesized.

Other research has posited that animosity affects CET (Shankarmahesh, 2006). Table 1 shows previous studies that have hypothesized this direction (Chan et al., 2010; De Nisco et al., 2016; Jimenez \& San MartÃn, 2010; Nijssen \& Douglas, 2004). The rationale for the impact of animosity on CET is that animosity that is targeted at a specific country can have a spill-over effect over multiple countries. As argued by Shankarmahesh (2006, p.162), "it is quite possible that consumers can generalize animosity towards a few foreign countries to all foreign countries". Therefore, as a result of this generalized animosity, consumers can develop beliefs that it is morally wrong to purchase foreign products.

In sum, to the best of our knowledge, no studies to date have tested the direct effect of CET on animosity. We propose the presence of such a direct effect for several reasons. First, as CET is a general belief, we argue that consumers may already possess this belief before they developed animosity towards a specific foreign country. For instance, ethnocentric 
consumers often embrace the belief that buying home country products is a good way of improving the economic situation in their home country. In this case, consumers' CET tendency might already be high without the presence of animosity towards a specific country. It is also plausible that when animosity is triggered by a certain event (e.g., a recent trade dispute with a foreign country), it may be intensified due to existing CET, leading to stronger reluctance to buy foreign products in general. Second, animosity is a country-specific construct, whereas CET is not country specific but directed towards all foreign countries (Hoffmann et al., 2011; Klein et al., 1998). Therefore, we argue that the spill-over effect from a general belief to a country-specific belief (i.e., from CET to animosity) is more likely to occur than the other way around (i.e., from animosity to CET). This leads us to the following hypothesis:

H8. Consumer ethnocentrism has a positive impact on economic animosity.

As hypothesized in the original Klein model (Klein et al.' 1998), we propose that ethnocentrism has a negative impact on foreign product judgment and a positive impact on consumers' reluctance to buy foreign products (Nijssen \& Douglas, 2004). This leads us to the following hypotheses:

H9. Consumer ethnocentrism has a negative impact on foreign product judgment.

H10. Consumer ethnocentrism has a positive impact on reluctance to buy foreign products.

We present our conceptual framework in Figure 1, and in Table 2 we list our hypotheses, providing a snapshot of the key theories and articles that support each proposed relationship in our model (see Figure 1). We also indicate in Table 2 whether the proposed relationships have been tested in past research. 
Figure 1. Model framework

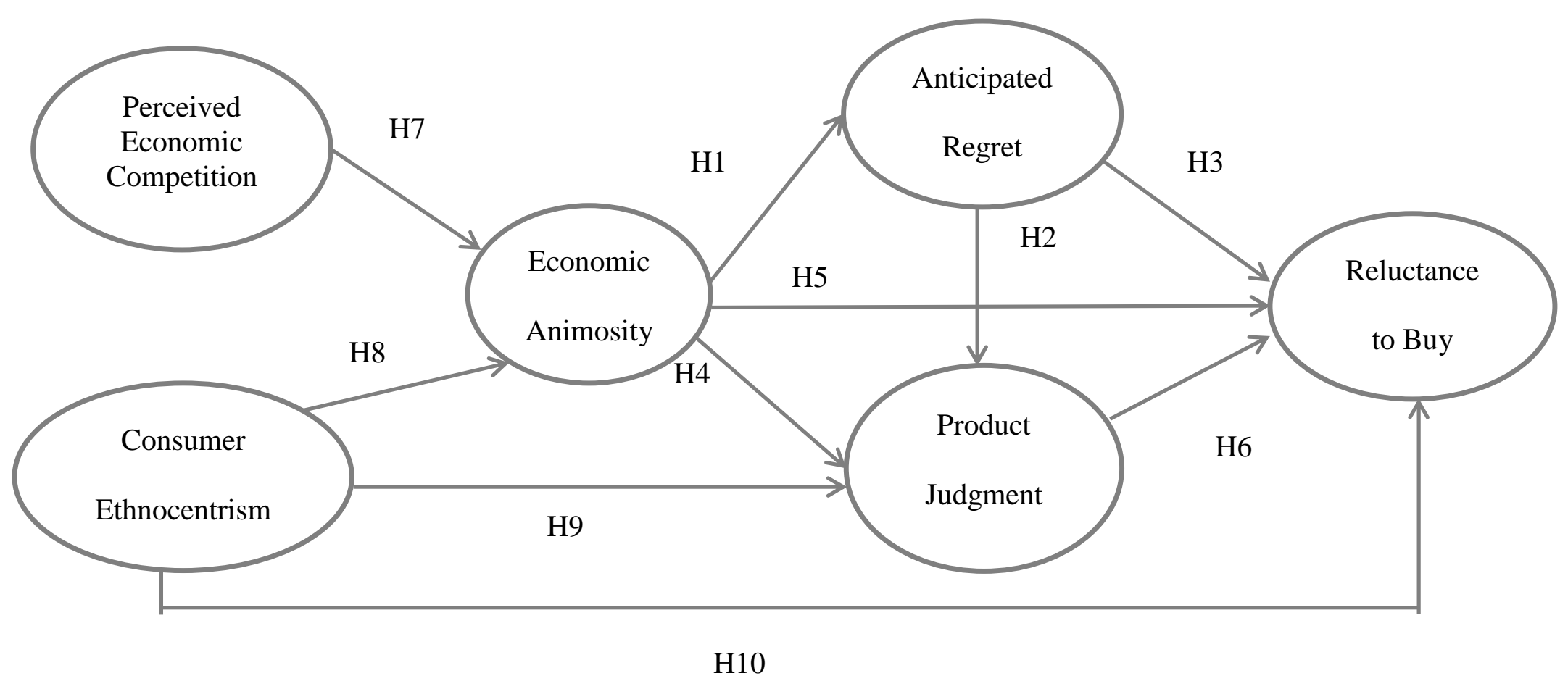


Table 2. An overview of new hypothesized relationships in our research and existing relationships in earlier studies

\section{Hypothesis}

H1. Economic animosity has a positive impact on anticipated regret.

H2. Anticipated regret has a negative impact on foreign product judgment.

H3. Anticipated regret has a negative impact on reluctance to buy foreign products.

H4. Economic animosity has a negative impact on foreign product judgment.

H5. Economic animosity has a positive impact on reluctance to buy foreign products.

H6. Foreign product judgment has a positive impact on reluctance to buy foreign products.

\section{Theoretical support}

\section{Outcome}

Janis and Mann (1977) Inman (2007)

Inman (2007)

Inman (2007)

Cognitive dissonance theory, Festinger (1962), Russell and Russell (2010), Shoham et al., (2006)

Cognitive dissonance theory (Jae-Woong et al., 2014; Su et al., 2011; Yu-An et al., 2010)

Self-defense mechanism theory (Baumeister et al.,
New finding for economic animosity effects.

New finding for anticipated regret effects.

New finding for anticipated regret effects.

New finding for economic animosity effects.

New finding for anticipated regret effects.

Tests existing finding in the new context of Taiwanese consumer attitudes toward South Korean 
Funk et al., (2010),

Nijssen and Douglas

(2004)

H6a. Anticipated regret mediates the effect of economic animosity on foreign product judgment.

H6b. Anticipated regret mediates the effect of economic animosity on consumers' reluctance to buy a foreign product.

H7. Perceived economic competition has a positive impact on economic animosity.

H8. Consumer Ethnocentrism has a positive impact on economic animosity.

Regret Theory

Regret Theory

Attribution theory; Leong et al., (2008)

Attribution theory; Leong et al., (2008)

H9. Consumer ethnocentrism has a negative impact on foreign product judgment.

H10. Consumer ethnocentrism has a positive impact on the reluctance to buy foreign products.
Klein (1998), Nijssen and Douglas (2004)

Klein, (1998, Nijssen and Douglas (2004)
New finding for anticipated regret effects.

New finding for anticipated regret effects.

New finding for economic competition effects.

New finding for ethnocentrism effects.

Tests existing finding in the new context of Taiwanese consumer attitudes toward South Korean electronics products.

Tests existing finding in the new context of Taiwanese consumer attitudes toward South Korean electronics products. 


\section{METHOD}

To test our proposed conceptual model, we chose Taiwan to represent the home market and South Korea to represent the target country of economic animosity. The relationship between Taiwan and South Korea is characterized by intense economic competition Both countries heavily invest in the electronic goods industry where intense competitions are frequent in both the local and global markets (e.g., HTC series and Samsung Galaxy series in smartphone markets; Asus and Samsung in laptop markets; Altek and Samsung in digital-camera markets) (Weathinasia, 2017). In addition, competition has intensified due to Taiwan and South Korea's close location proximity (i.e., neighbouring countries or economic entities). We thus see the economic rivalry between Taiwan and South Korea as an appropriate context to test the hypotheses of the proposed conceptual model of economic animosity (see Figure 1).

\subsection{Measures}

The survey contained items measuring key constructs in the model: economic animosity (four items) (Klein et al., 1998), self-developed items to measure anticipated regret (two items), product attitude (five items) (Perkins \& Forehand, 2012) and reluctance to buy South Korean products (four items) (Nijssen \& Douglas, 2004). All items, except for product judgment, were measured using 7-point Likert scales anchored from strongly disagree to strongly agree (7). Product judgment was measured using 7-point semantic differential scale (e.g., badgood) (Perkins \& Forehand, 2012). The reliability coefficients for all scales exceeded 0.70 . The survey also included items measuring demographics (e.g. gender and level of education). A translation and back translation procedure was applied to present the survey in Mandarin (the official language in Taiwan). 


\subsection{Sample}

We collected data from Taiwanese consumers $(\mathrm{N}=208)^{2}$ (Republic of China) via an online survey measuring respondents' opinions about South Korean electronic products. We developed our questionnaire using Qualtrics, which is one of the most widely used questionnaire development software tools. A link to the questionnaire was posted on the two dominant social media platforms in Taiwan: Facebook and Line. Respondents were also encouraged to share the link among their own social networks. Reminders were also sent via the social media accounts after few days to encourage participation. The sample consisted of $54 \%$ males. More than $80 \%$ had a bachelor degree or higher, $9 \%$ were aged below $20,23 \%$ between 20 and 29, 25\% between 30 and 39, 12\% between 40 and 49,24\% between 50 and 59 , and $7 \%$ above 60 .

\subsection{Reliability and validity assessment}

All measures were subjected to confirmatory factor analysis (CFA) to evaluate the convergent and discriminant validity of each construct (Bagozzi \& Yi, 2012), using AMOS 22. We performed CFA of all correlated factors in the model, which shows a good fit with the data: $\chi 2(416)=588.71 ;$ TLI=.969, CFI=.973; RMSEA=.045, SRMR=.05. Table 3 shows the measurement items with their standardized loadings and Cronbach's alpha. Our results show that all measures exhibit strong internal validity in both countries. Composite reliability for each scale is greater than .7 (Fornell \& Larcker, 1981). Convergent validity assessed by Average Variance Extracted (AVE) indicates that all constructs have a higher AVE than the benchmark of .5. To assess discriminant validity, the square root of the AVE for all

\footnotetext{
${ }^{2}$ It is important to note here that although the sample size is around $n=208$, we used bootstrapping techniques generating 1000 bootstrap sample to calculate the parameter estimates and their standard errors. The model still produces a good fit to the data. In fact, Iacobucci (2010 p94) showed with her Monte Carlo studies that "if the variables are reliable, the effects are strong, and the model not overly complex, smaller samples will suffice".
} 
constructs was greater than all corresponding correlations (Fornell \& Larcker, 1981) (See Table 4)

Table 3. Measurement items and loadings

\begin{tabular}{|c|c|c|c|}
\hline Construc & Item & Wording & $\mathrm{SL}^{\mathrm{a}}$ \\
\hline \multirow[t]{5}{*}{ EAN } & AN4 & South Korea is not a reliable trading partner. & 0.78 \\
\hline & AN5 & South Korea wants to gain economic power over Taiwan. & 0.82 \\
\hline & AN6 & The South Koreans are doing business unfairly with the & \\
\hline & & Taiwanese. & 0.71 \\
\hline & AN7 & South Korea is taking advantage of Taiwan. & 0.91 \\
\hline \multirow[t]{7}{*}{ CET } & CE2 & Purchasing foreign-made products is un-Taiwanese. & 0.71 \\
\hline & CE3 & A real Taiwanese should always buy products made in Taiwan. & 0.78 \\
\hline & CE4 & $\begin{array}{l}\text { We should purchase products manufactured in Taiwan instead of } \\
\text { letting other countries make money out of us. }\end{array}$ & 0.79 \\
\hline & CE5 & Taiwanese should not buy foreign products, because this damages & \\
\hline & & Taiwan business and causes unemployment. & 0.93 \\
\hline & CE6 & $\begin{array}{l}\text { Taiwanese consumers who purchase non-Taiwanese products are } \\
\text { responsible for putting their fellow Taiwanese out of jobs. }\end{array}$ & 0.83 \\
\hline & CE7 & $\begin{array}{l}\text { We should only buy foreign products if we cannot buy them in our } \\
\text { own country. }\end{array}$ & 0.78 \\
\hline \multirow[t]{7}{*}{ PEC } & PEC1 & $\begin{array}{l}\text { There is intense economic competition between Taiwan and South } \\
\text { Korea. }\end{array}$ & 0.89 \\
\hline & PEC2 & $\begin{array}{l}\text { Economic competition between Taiwan and South Korea is very } \\
\text { intense. } \\
\text { Taiwanese companies compete directly with South Korean }\end{array}$ & 0.90 \\
\hline & PEC3 & companies. & 0.85 \\
\hline & PEC4 & Taiwan faces pressing economic challenges from South Korea. & 0.91 \\
\hline & PEC5 & South Korea threatens Taiwanese exports. & 0.83 \\
\hline & PEC6 & $\begin{array}{l}\text { Taiwan and South Korea are highly competitive in the economic } \\
\text { sector. }\end{array}$ & 0.92 \\
\hline & PEC7 & $\begin{array}{l}\text { The degree of economic competition between Taiwan and South } \\
\text { Korea is very high. }\end{array}$ & 0.89 \\
\hline
\end{tabular}

Regret If I bought South Korean electronic products...

$\begin{array}{lll}\text { REG1 I would feel regretful. } & 0.97\end{array}$

$\begin{array}{ll}\text { REG2 I would feel sorry about my purchase decision. } & 0.97\end{array}$

$\begin{array}{ll}\text { REG3 I would feel like I was a bad person. } & 0.72\end{array}$

$\begin{array}{ll}\text { REG5 I would feel that others would judge me. } & 0.84\end{array}$

PJ I think South Korean electronic products are

$\begin{array}{lll}\text { PJ1 Bad-Good } & 0.88\end{array}$

$\begin{array}{ll}\text { PJ2 Low quality-High quality } & 0.91\end{array}$

$\begin{array}{ll}\text { PJ3 Very unreliable - Very reliable } & 0.96\end{array}$ 
PJ4 Not very durable - Very durable

PJ5 Very bad value for money -Very good value for money

REL REL1 Whenever possible, I avoid buying South Korean Products.

REL2 If two products were equal in quality, but one was from Taiwan and one was from South Korea, I would pay $10 \%$ more for the Taiwanese product.

REL4 I would never buy a South Korea product.

REL5 I do not like the idea of owning a camera that was manufactured in South Korea.

${ }^{\mathrm{a}}=$ Standardized loadings, EAN=Economic animosity; CET=Consumer ethnocentrism;

$\mathrm{PJ}=$ product judgment; REL $=$ reluctance to buy. $\mathrm{CFA}$ model fit indices: $\chi 2=588.71, \mathrm{df}=416$, RMSEA=0.045; SRMR=0.05; CFI=0.973; TLI=0.969.

Table 4. Correlations among latent constructs

\begin{tabular}{llllllllc}
\hline Construct & CR & AVE & 1. & 2. & 3. & 4. & 5. & 6. \\
\hline 1. PEC & 0.96 & 0.79 & $\mathbf{0 . 8 9}$ & & & & & \\
2. CET & 0.92 & 0.67 & $0.10 \mathrm{~ns}$ & $\mathbf{0 . 8 2}$ & & & & \\
3. EAN & 0.92 & 0.69 & 0.44 & 0.35 & $\mathbf{0 . 8 3}$ & & & \\
4. REG & 0.93 & 0.77 & 0.31 & 0.23 & 0.48 & $\mathbf{0 . 9 6}$ & & \\
5. PJ & 0.96 & 0.81 & $0.03 \mathrm{~ns}$ & $-0.14 \mathrm{~ns}$ & -0.26 & -0.42 & $\mathbf{0 . 9 0}$ & \\
6. REL & 0.91 & 0.72 & 0.34 & 0.35 & 0.51 & 0.61 & -0.49 & $\mathbf{0 . 8 5}$ \\
\hline
\end{tabular}

All correlation coefficients are significant at $\mathrm{p}<0.01$, except those indicated with $\mathrm{ns}=$ not significant, square root of AVEs are in bold in the main diagonal.

Given the use of a self-reported rating scale, we tested for possible common method bias by Harman's single factor: if the data have a serious common method bias, a single latent factor will account for all or most items (Podsakoff \& Organ, 1986). To test for this bias, we specified our model as a single-factor, and then fit the data in a CFA model to test for fit versus the null model. A poor fitting model will indicate that there is no single factor that may explain most of the common variance in the measures (Mossholder, Kemery, Bennett, \& Wesolowski, 1998). The one-factor model showed a poor fit to the data $(\chi 2(431)=4073.45$, $\mathrm{TLI}=.37$; $\mathrm{CFI}=.42$; RMSEA=.20), suggesting common-method bias is not a serious threat to the measurement validity of the model. 


\section{RESULTS}

We used AMOS ver. 22 to test our hypotheses. Model indices give an acceptable fit of data to the model $(\chi 2=613.63, \mathrm{DF}=422, \mathrm{RMSEA}=0.04$ (CI: 0.039-0.055), CFI=0.97, TLI=0.97, SRMR=0.07). Our results are presented in Figure 2.

Economic animosity has a positive impact on anticipated regret, supporting $\mathrm{H} 1(\beta=0.48, \mathrm{t}=$ 6.79) and reluctance to buy foreign pro- ducts, supporting $\mathrm{H} 5(\beta=0.25, \mathrm{t}=3.68)$, but its impact on product judgment $(\beta=-0.07, \mathrm{t}=-0.82)$ is insignificant, thus rejecting $\mathrm{H} 4$. Anticipated regret has a significant negative impact on product judg- ment $(\beta=-0.36, \mathrm{t}=$ -4.59), and a positive impact on reluctance to buy foreign products $(\beta=0.41, t=5.76)$, thus supporting both $\mathrm{H} 2$ and $\mathrm{H} 3$. Product judgment has a significant negative impact on reluctance to buy $(\beta=-.23, \mathrm{t}=-3.73)$, supporting H6.

Regarding the antecedents of animosity, the results suggest that CET has a positive impact on economic animosity, supporting $H 8(\beta=0.31, \mathrm{t}=4.36)$, and on reluctance to buy $(\beta=0.14, \mathrm{t}$ = 2.32) supporting $\mathrm{H} 9$, and perceived economic competition has a positive impact on economic animosity, thus supporting $\mathrm{H} 7(\beta=0.43, \mathrm{t}=6.37)$. However, the effect of CET on product judgment is insignificant $(\beta=-0.3, \mathrm{t}=-0.47)$, thus $\mathrm{H} 10$ is not supported. 
Figure 2. Results (standardized path coefficients)

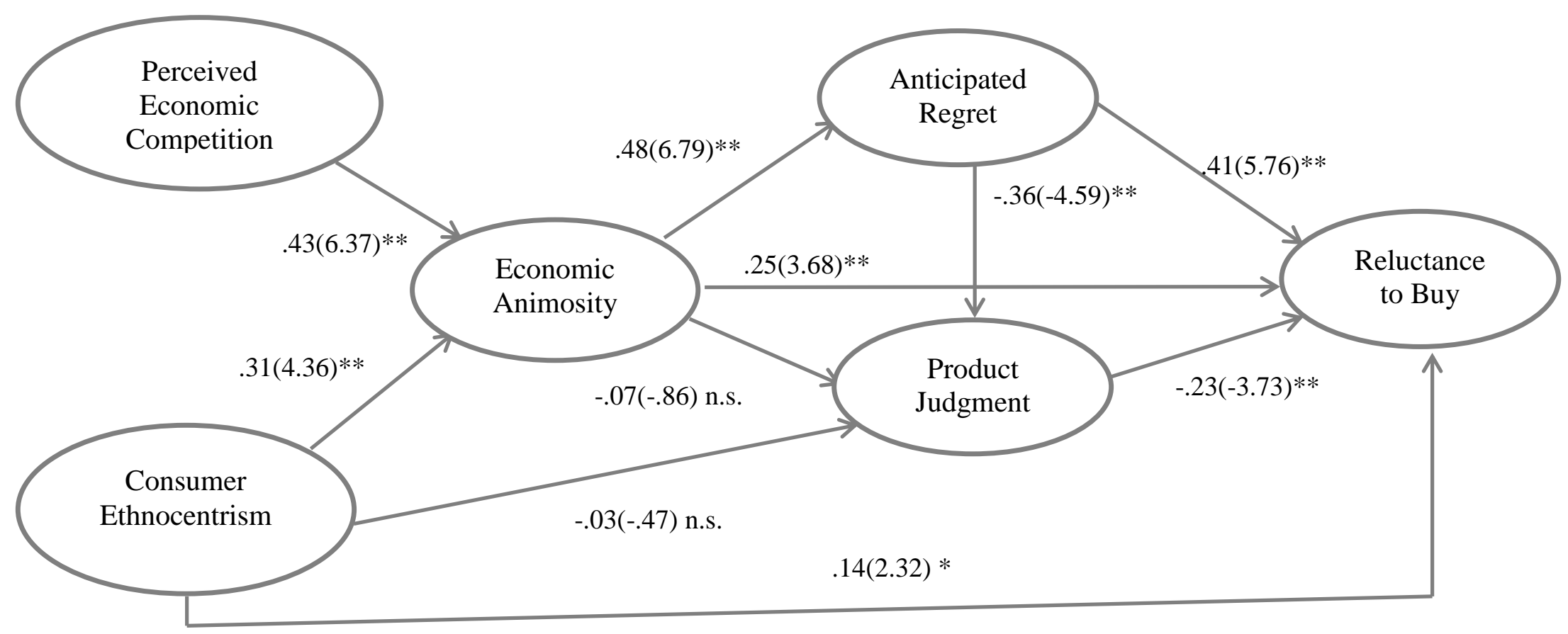




\subsection{Testing the mediation effect of regret}

In our theoretical framework, anticipated regret mediates the effect of economic animosity on product judgment and reluctance to buy. To assess the strength of the mediation effect, we perform indirect effect test using AMOS with 1000 bootstrap samples. The bootstrap procedure was recommended to test the mediation effect because it did not rely on the normal distribution assumption for the sampling distribution of the indirect effects (MacKinnon, 2008; Shrout \& Bolger, 2002). We specify three user-defined standardized path estimates in AMOS visual basic scripts representing the three routes in which economic animosity affects reluctance to buy a foreign product mediated by anticipated regret: (1) the effect of economic animosity (EAN) on product judgment (PJ) via anticipated regret (REGRET) $($ EAN $\rightarrow$ REGRET $\rightarrow$ PJ), (2) the effect of economic animosity on reluctance to buy (REL) via anticipated regret $($ EAN $\rightarrow$ REGRET $\rightarrow$ REL) and (3) the effect of economic animosity on reluctance to buy via anticipated regret and product judgment, respectively $(\mathrm{EAN} \rightarrow \mathrm{REGRET} \rightarrow \mathrm{PJ} \rightarrow \mathrm{REL})$.

The results of the indirect effect analysis, presented in Table 5, show the standardized estimates of the indirect effects and their standard errors, p-value associated with the estimates and the lower bound and upper bound of the bias-corrected confidence intervals. The results suggest that (1) anticipated regret mediates the effect of economic animosity on product judgment $(\beta=-.173$, se=.052, $\mathrm{p}<.01)$, (2) anticipated regret mediates the effect of economic animosity on reluctance to buy a foreign product $(\beta=.195$, se $=.052, \mathrm{p}<.01$, supporting H6a), (3) the indirect effect of economic animosity through anticipated regret and product judgment is significant $\left(\beta=.040, \mathrm{se}=.019, \mathrm{p}<.01 ; \beta_{\mathrm{US}}=-.072, \mathrm{p}<.01\right.$, supporting $\left.\mathrm{H} 6 \mathrm{~b}\right)$. Together, these results show that anticipated regret triggered by economic animosity has a significant role in affecting product judgment and reluctance to buy a foreign product. 
Table 5. Standardized indirect effects (1000 bootstrap samples)

\begin{tabular}{lccc}
\hline \multicolumn{1}{c}{ Path } & Estimate $(\mathrm{se})$ & p-value & CI (LB,UB) \\
\hline EAN $\rightarrow$ REGRET $\rightarrow$ PJ & $-.173(.052)$ & $.002^{* *}$ & $-.267,-.088$ \\
EAN $\rightarrow$ REGRET $\rightarrow$ REL & $.195(.052)$ & $.002^{* * *}$ & $-.116, .286$ \\
EAN $\rightarrow$ REGRET $\rightarrow$ PJ $\rightarrow$ REL & $.040(.019)$ & $.001^{* *}$ & $.017, .082$ \\
& & & \\
\hline $\begin{array}{l}\text { Note: }{ }^{* *} \text { p <.01; ns=not significant; Note: EAN=Economic Animosity, } \\
\text { REGRET=Anticipated regret, PJ=Product judgment, REL=reluctance to } \\
\text { buy foreign products, CI=bias-corrected confidence interval, LB=lower } \\
\text { bound, UB=upper bound. }\end{array}$
\end{tabular}

\section{DISCUSSION}

Our research reveals new important relationships in relation to the impact of animosity on consumer preferences. Our study extends previous work on animosity by uncovering the underlying mechanism through which animosity affects consumers' foreign product judgment and purchase decisions. We focused on economic animosity in the context of intense economic competition between Taiwan (HTC) and South Korea (Samsung: the target of economic animosity). This has furthered our understanding of economic animosity, a construct that has been largely overlooked in the literature. Drawing on regret theory, we also contribute to existing animosity literature by explaining how anticipated regret can explain the negative effect of economic animosity on consumers' foreign product judgment and their reluctance to buy. This is because consumers may experience regret if they bought a foreign product from an economic rival. For example, their CET may be questioned by their significant others (e.g., no fellowship feelings). Following Janis \& Mann's regret theory (1977), we thus propose and demonstrate that anticipated regret, in this case, serves as a preventive strategy to mitigate unwanted or unpleasant feelings (e.g., peer pressure) that may occur if a foreign product from an economic rival is purchased. 
The unique contribution of this paper is the identification of the mediation role of anticipated regret in the relationship between economic animosity and consumers' reactions towards a foreign product (i.e., product judgment and reluctance to buy a product). Our study makes the following contributions to the existing literature. First, it contributes to regret literature by demonstrating that economic animosity can induce anticipated regret when making a decision to purchase a product from a target country of animosity. Economic animosity, to the best of our knowledge, has never been examined as a factor that can trigger anticipated regret. Second, this research also contributes to the country-of-origin literature by showing how the economic animosity affects the judgment of foreign product quality. This research fills a knowledge gap by showing how anticipated regret as a moral emotion, may function as a mechanism through which animosity affects foreign product judgment. Finally, we also contribute to animosity literature by demonstrating the antecedents of economic animosity: perceived economic competition and consumer ethnocentrism, improving our understanding of the formation of economic animosity.

\subsection{Research implications}

Recent research on animosity (Harmeling et al., 2015; Nes et al., 2012) has revealed the role of affect (e.g., agonistic/retreat emotion, psychosocial affect) in explaining the influence of animosity on purchase decisions. Although current research also shares a focus on emotions (i.e., regret), we differ from previous research in important ways. For example, Harmeling et al. focused on emotions that consumers felt (e.g. agnostic, anger vs. retreat, fear) toward the target country of animosity and examined the impact of these emotions on consumers' foreign product judgment. They found that although anger and fear are both possible responses to animosity beliefs, they drive different behavioral consequences. For example, angry customers did not denigrate product quality, but would avoid buying the product and 
tended to spread negative word-of-mouth about the product (e.g., discouraging friends to buy it). In contrast, customers who experienced fear, not only avoided buying a product, but also denigrated product quality. However, they were less likely to spread negative word-of-mouth. In our study, we did not measure consumers' feelings toward a target country of animosity per se post-consumption. Instead, we focused on consumers' anticipated emotions (i.e., regret) toward their decision-making outcomes in relation to consumption choices. Hence, unlike anger and fear, anticipated regret in our study is a "cognitive emotion that people are motivated to regulate in order to maximize outcomes in the short term and learn maximizing them in the long run" (Zeelenberg \& Pieters, 2007, p.4). Therefore, in our study we implicitly assume that when consumers form economic animosity beliefs, they are motivated to regulate their affective experience (i.e., regret) with respect to purchasing a foreign product from a target country of animosity. Another difference between our study and Harmeling, Magnusson, and Singh (2015) is that they only considered war animosity. We instead focused on economic animosity - Taiwan and South Korea have not had military conflicts in the past. Our findings point to a strong influence of perceived economic rivalry in the formation of economic animosity. This finding corroborates earlier results (Harris, 2013).

Furthermore, Nes et al. (2012) also discussed the role of psychosocial affect and developed and operationalized it as a multifaceted emotion (e.g., guilt, embarrassment and self-image). In their study, however, each type of emotion was measured by a single item, and then averaged to reflect psychosocial affect as a whole. We argue that because of the weak and general conceptualization of psychosocial affect, the specific emotion that mediates the effect of animosity on purchase decisions remains unclear. We focused on the emotion of anticipated regret, thus enabling a more nuanced understanding of the specific emotional effect on consumers' purchase decisions (e.g., foreign product judgment). 
Finally, our research adds to past literature on the link between consumer ethnocentrism and economic animosity. One of the key tenets in the original animosity model is that there is no relationship between consumer ethnocentrism and economic animosity (Klein et al., 1998). However, subsequent research has examined the link between the two constructs and has provided some rationale for the relationship. Our literature review reveals that the majority of the studies following Klein et al.'s (1998) original model presented the relationship as correlational with a few studies also hypothesizing a direct link from animosity to CET. In our research, we modelled the opposite effect and our findings support this effect (i.e., from CET to animosity). Such an effect occurs because CET may exist prior to the development of animosity beliefs, and unlike animosity, CET is not targeted at a specific foreign country.

\subsection{Managerial implications}

In line with past research (e.g., Leong et al., 2008), our findings suggest that having a quality product may not be sufficient to offset the negative effect of animosity on consumers' willingness to purchase. Specifically, our study highlights how economic animosity could lead to the development of anticipated regret, which undermines consumers' foreign product judgment. The managerial implication of this particular finding related to the activation of anticipated regret following animosity is that marketers from a target country of animosity should actively engage with consumers in corrective processes. For example, marketers can

make consumers aware of the source of their anticipated regret via advertising and communication strategies. In so doing, consumers may be afforded an opportunity to correct their bias, thus preventing the translation of economic animosity to negative product judgment. Indeed, according to Schwartz and Clore (1983), when consumers are made aware of the source of their negative feelings, they are more likely to correct these emotions (e.g., 
less likely to find a rationale for feeling this way), thus encouraging consumers to be fairer in their judgment of the foreign product quality.

Due to the effect of globalization, (perceived) economic competitions are expected to intensify over time. This implies that it will be more difficult to overcome the negative effect of economic animosity and we therefore argue that the affective experience of anticipated regret will play a more significant role in consumers' purchase decisions. Thus, international marketers should be mindful of such effects when entering or operating in a foreign market.

More generally speaking, by understanding the antecedents of economic animosity (i.e., perceived economic competition and consumer ethnocentrism), international marketers could devise strategies that downplay country linkages that may arouse economic animosity and anticipated regrets. For example, they could focus on promoting features of their offerings that are less related to the country of origin (e.g., promotion with no country-oforigin linkages or offerings that fit into the consumer culture of the target market). Since consumer ethnocentrism positively influences consumers' willingness to purchase, international marketers can emphasize the relevance/benefit of their product offerings by, for instance, forming collaborations with the marketed economy for joint product creation. Promotional campaigns could emphasize such collaborations to lessen the economic animosity consumers may experience toward a competing economy.

\subsection{Limitations and future research direction}

This section identifies limitations and avenues for further research. First, this research did not test the underlying mechanisms in which animosity affects anticipated regret. Further studies can devote attention to potential variables that serve as the mediators of this relationship. Second, we suggest that future research should closely re-examine the influence of context on the direction of the relationship between animosity and consumer ethnocentrism, as findings 
from both previous and present research have been mixed. Our findings suggest that the relationship might be contingent on the research context. For example, consumer ethnocentrism might be more intense in a context where situational animosity arises (e.g., recent economic conflict) rather than the other way round. Third, we focused on consumers' anticipated regret in a specific cultural context (i.e., Taiwanese consumers; a largely collectivist society). Findings from recent research on regret revealed that there are crosscultural differences in the experience of regret (Breugelmans, Zeelenberg, Gilovich, Huang, \& Shani, 2014). For instance, US consumers are more likely to experience regret in situations where a 'bad' decision only affects themselves, and regret can transform into guilt when the decision also has a negative impact on others (e.g., feeling regretful when buying a foreign product that is counter to CET, and feeling guilty when their significant others are let down by the product purchase, e.g., no fellowship feelings). However, in Taiwan, regret is said to be more likely to occur and felt more intensely in situations of interpersonal harm (Breugelmans et al., 2014). Future research could explore how cultural variations may affect the relationship between animosity and regret and could provide new insights into the boundary conditions of the relationship. Furthermore, this research focused on Taiwan, future research may test whether our findings are replicable to other countries by employing a bigger sample. Moreover, we did not inform our respondents that Taiwanese electronic products such as HTC mobile phones have been found to contain South Korean electronic components. Additional research is needed to broaden extant understanding of the effect of disclosing such information on animosity beliefs.

Finally, yet importantly, in this research we have assumed that consumers will be made aware of the country-of-origin through product labeling as they consider which product to buy. We did not consider situations when this is not the case. For example, consumers may access the country-of-origin information from other sources (e.g., family, friends or wider 
social networks) or understand that specific brand names will reveal information about the products' country-of-origin. It will be interesting to know whether anticipated regret will also arise in these types of situations and to what extent (in the case of products from the target country/market of economic animosity). This is because when the negative country-of-origin information is learnt through word of mouth, the anticipated regret may be strengthened as the consumer may then be primed to avoid social exclusion (Mead, Baumeister, Stillman, Rawn \& Vohs (2011). 


\section{References}

Bagozzi, R., \& Yi, Y. (2012). Specification, evaluation, and interpretation of structural equation models. Journal of the Academy of Marketing Science, 40(1), 8-34.

Baron, R. M., \& Kenny, D. A. (1986). The moderator-mediator variable distinction in social psychological research: Conceptual, strategic, and statistical considerations. Journal of Personality and Social Psychology, 51(6), 1173.

Baumeister, R. F., Masicampo, E. J., \& Vohs, K. D. (2011). Do conscious thoughts cause behavior? Annual Review of Psychology, 62, 331-361.

Baumeister, R. F., Dale, K., \& Sommer, K. L. (1998). Freudian defense mechanisms and empirical findings in modern social psychology: Reaction formation, projection, displacement, undoing, isolation, sublimation, and denial. Journal of Personality, 66(6), $1081-1124$.

Breugelmans, S. M., Zeelenberg, M., Gilovich, T., Huang, W.-H., \& Shani, Y. (2014). Generality and cultural variation in the experience of regret. Emotion, 14(6), 1037-1048.

Chan, T. S., Chan, K. K., \& Leung, L.-c. (2010). How consumer ethnocentrism and animosity impair the economic recovery of emerging markets. Journal of Global Marketing, 23(3), $208-225$.

Connolly, T., \& Zeelenberg, M. (2002). Regret in decision making. Current Directions in Psychological Science, 11(6), 212-216.

De Nisco, A., Mainolfi, G., Marino, V., \& Napolitano, M. R. (2016). Effect of economic animosity on consumer ethnocentrism and product-country images. A binational study on perception of Germany during the Euro crisis. European Management Journal.

Festinger, L. (1962). A theory of congitive dissonance. Stanford University Press.

Fornell, C., \& Larcker, D. F. (1981). Structural equation models with unobservable variables 
and measurement error: Algebra and statistics. Journal of Marketing Research, 18(3), $382-388$.

Funk, C. A., Arthurs, J. D., Treviño, L. J., \& Joireman, J. (2010). Consumer animosity in the global value chain: The effect of international production shifts on willingness to purchase hybrid products. Journal of International Business Studies, 41(4), 639-651.

Harmeling, C. M., Magnusson, P., \& Singh, N. (2015). Beyond anger: A deeper look at consumer animosity. Journal of International Business Studies, 46(6), 676-693.

Harris, B. (2013). Taiwan's rivalry with South Korea reveals anxiety assessed 25/02/2014. http://www.scmp.com/news/china/article/1371825/taiwans-rivalry-south-koreareveals-anxiety.

Hoffmann, S., Mai, R., \& Smirnova, M. (2011). Development and validation of a crossnationally stable scale of consumer animosity. The Journal of Marketing Theory and Practice, 19(2), 235-252.

Iacobucci, D. (2010). Structural equations modeling: Fit indices, sample size, and advanced topics. Journal of Consumer Psychology, 20.1, 90-98.

Inman, J. J. (2007). Regret regulation: Disentangling self-reproach from learning. Journal of Consumer Psychology (Lawrence Erlbaum Associates), 17(1), 19-24.

Jae-Woong, Y. O. O., Samsup, J. O., \& Jaemin, J. (2014). The effects of television viewing, cultural proximity, and ethnocentrism on country image. Social Behavior and Personality an International Journal, 42(1), 89-96.

Janis, I. L., \& Mann, L. (1977). Decision making: A psychological analysis of conflict, choice, and commitment. Free Press.

Jimenez, N. H., \& San MartÂn, S. (2010). The role of country-of-origin, ethnocentrism and animosity in promoting consumer trust. The moderating role of familiarity. International Business Review, 19(1), 34-45. 
Klein, J. G. (2002). Us versus them, or us versus everyone? Delineating consumer aversion to foreign goods. Journal of International Business Studies, 33(2), 345-363.

Klein, J. G., Ettenson, R., \& Morris, M. D. (1998). The animosity model of foreign product purchase: An empirical test in the People's Republic of China. Journal of Marketing, 62(1), 89-100.

Leong, S. M., Cote, J. A., Ang, S. H., Tan, S. J., Jung, K., Kau, A. K., et al. (2008). Understanding consumer animosity in an international crisis: Nature, antecedents, and consequences. Journal of International Business Studies, 39(6), 996-1009.

MacKinnon, D. P. (2008). Introduction to statistical mediation analysis. Lawrence Erlbaum Associates.

Maher, A. A., Clark, P., \& Maher, A. (2010). International consumer admiration and the persistence of animosity. The Journal of Consumer Marketing, 27(5), 414-424.

Mead, N. L., Baumeister, R. F., Stillman, T. F., Rawn, C. D., \& Vohs, K. D. (2011). Social exclusion causes people to spend and consume strategically in the service of affiliation. The Journal of Consumer Research, 37(5) 902-19.

Mossholder, K. W., Kemery, E. R., Bennett, N., \& Wesolowski, M. A. (1998). Relationships between bases of power and work reactions: The mediational role of procedural justice. Journal of Management, 24(4), 533-552.

Nes, E. B., Yelkur, R., \& Silkoset, R. (2012). Exploring the animosity domain and the role of affect in a cross-national context. International Business Review, 21(5), 751-765.

Nijssen, E. J., \& Douglas, S. P. (2004). Examining the animosity model in a country with a high level of foreign trade. International Journal of Research in Marketing, 21(1), 23-38.

Parker, R. S., Haytko, D. L., \& Hermans, C. M. (2011). Ethnocentrism and its effect on the Chinese consumer: A threat to foreign goods? Journal of Global Marketing, 24(1), 4-17.

Perkins, A. W., \& Forehand, M. R. (2012). Implicit self-referencing: The effect of non- 
volitional self-association on brand and product attitude. The Journal of Consumer Research, 39(1), 142-156.

Pieters, R. (2017). Meaningful mediation analysis: Plausible causal inference and informative communication. The Journal of Consumer Research, 44(3), 692-716.

Podsakoff, P. M., \& Organ, D. W. (1986). Self-reports in organizational research: Problems and prospects. Journal of Management, 12(4), 531.

Rose, M., Rose, G. M., \& Shoham, A. (2009). The impact of consumer animosity on attitude towards foreign goods: A study of Jewish and Arab Israelis. The Journal of Consumer Marketing, 26(5), 330-339.

Russell, C. A., \& Russell, D. W. (2010). Guilty by stereotypic association: Country animosity and brand prejudice and discrimination. Marketing Letters, 21(4), 413-425.

Schwarz, N., \& Clore, G. L. (1983). Mood, misattribution, and judgments of well-being: Informative and directive functions of affective states. Journal of Personality and Social Psychology, 45(3), 513.

Shankarmahesh, M. N. (2006). Consumer ethnocentrism: An integrative review of its antecedents and consequences. International Marketing Review, 23(2), 146-172.

Shih, E., \& Schau, H. J. (2011). To justify or not to justify: The role of anticipated regret on consumers' decisions to upgrade technological innovations. Journal of Retailing, 87(2), $242-251$.

Shimp, T. A., \& Sharma, S. (1987). Consumer ethnocentrism: Construction and validation of the CETSCALE. Journal of Marketing Research, 24(3), 280-289.

Shoham, A., Davidow, M., Klein, J. G., \& Ruvio, A. (2006). Animosity on the home front: The intifada in Israel and its impact on consumer behavior. Journal of International Marketing, 14(3), 92-114.

Shrout, P. E., \& Bolger, N. (2002). Mediation in experimental and nonexperimental studies: 
New procedures and recommendations. Psychological Methods, 7(4), 422-445.

Su, H. J., Huang, Y.-A., Brodowsky, G., \& Kim, H. J. (2011). The impact of product placement on TV-induced tourism: Korean TV dramas and Taiwanese viewers. Tourism Management, 32(4), 805-814.

Wang, W., He, H., \& Li, Y. (2012). Animosity and willingness to buy foreign products: Moderating factors in decision-making of Chinese consumers. Asia Pacific Business Review, 19(1), 32-52.

Wealthinasia (2017). Opportunities in Asia, South Korea Vs. Taiwan: Battle of the Asian tech giants. December, wealthinasia.com 1-2 (Accessed 28 December 2017).

Yu-An, H., Phau, I., \& Lin, C. (2010). Consumer animosity, economic hardship, and normative influence. European Journal of Marketing, 44(7/8), 909-937.

Zeelenberg, M. (1999). Anticipated regret, expected feedback and behavioral decision making. Journal of Behavioral Decision Making, 12(2), 93-106.

Zeelenberg, M., \& Pieters, R. (2007). A theory of regret regulation 1.0. Journal of Consumer Psychology (Lawrence Erlbaum Associates), 17(1), 3-18.

Zhao, X., Lynch, J. G., Jr, \& Chen, Q. (2010). Reconsidering Baron and Kenny: Myths and truths about mediation analysis. The Journal of Consumer Research, 37(2), 197-206. 